\title{
The effects of taxes and benefits on household income, 2007/08
}

Andrew Barnard

Office for National Statistics

\section{SUMMARY}

This article looks at how taxes and benefits affect the income of households in the UK. It provides estimates of the average amount of taxes paid, and the value of benefits received, for households with different levels of income. It also shows how the estimates are different for various types of households, according to factors such as whether the household is retired, and the number of adults and children living in the household. The analysis also examines how income inequality has changed over time. The analysis is published annually and results are presented here for 2007/08. Appendix 1 (21 additional tables) and Appendix 2 (Methodology and Definitions) are available on the web version of this article at www.statistics.gov.uk/cci/article. asp?id2257
T he incomes of households are altered by government intervention, through taxes and benefits. In general, households with the highest amount of income pay more in taxes than they receive in benefits, while the reverse is true for those with lower incomes. Taxes and benefits therefore decrease the inequality of income. In 2007/08, before taxes and benefits, the top fifth of households had an average of $£ 72,600$ per year in income from sources such as earnings, occupational pensions and investments (defined as original income). This is approximately 16 times as great as the figure of $£ 4,700$ for the bottom fifth. After taking account of all taxes and benefits, the top fifth had an average final income of $£ 52,400$ per year compared with $£ 14,300$ for the bottom fifth of households, a ratio of four to one. The difference between original income and final income for 2007/08, broken down by quintiles, is also shown graphically in Figure 1.

Cash benefits play the largest part in reducing inequality. Figure 2 shows the extent to which cash benefits increase the income of households, by income quintile group. It can be seen that the majority of cash benefits go to households with the lowest incomes. When cash benefits are added to a household's original income it forms their gross income.

Direct taxes (income tax, employees' National Insurance contributions and council tax and Northern Ireland rates), except for council tax and Northern Ireland rates, are progressive - they take a larger proportion of income from those with higher incomes. Therefore, they also contribute to a reduction in inequality although not to the same extent as cash benefits. Indirect taxes (taxes on final goods and services, such as VAT, and intermediate taxes, such as employers' National Insurance contributions) have the opposite effect to direct taxes taking a higher proportion of income from those with lower incomes, that is, they are regressive. While households higher up the income distribution pay more indirect tax in absolute terms, they pay a lower proportion of their income in indirect tax.

Households also receive benefits in kind from services provided free or at subsidised prices by government, such as health and education services. The amount of benefits in kind received falls gradually as income increases, indicating that they also lead to a reduction in inequality.

\section{Household characteristics}

Households can be grouped according to the number of adults and children living in the household, and according to whether the household is retired or not. Grouping households allows for analysis of how the tax and benefit system affects different types of households. Additionally, some types of households are more likely to have high incomes, whereas others tend to have lower incomes. This is presented in Table 4.

Single person households are slightly more likely to have higher incomes, while households consisting of two adults with no children, are very clearly concentrated in the higher groups. 


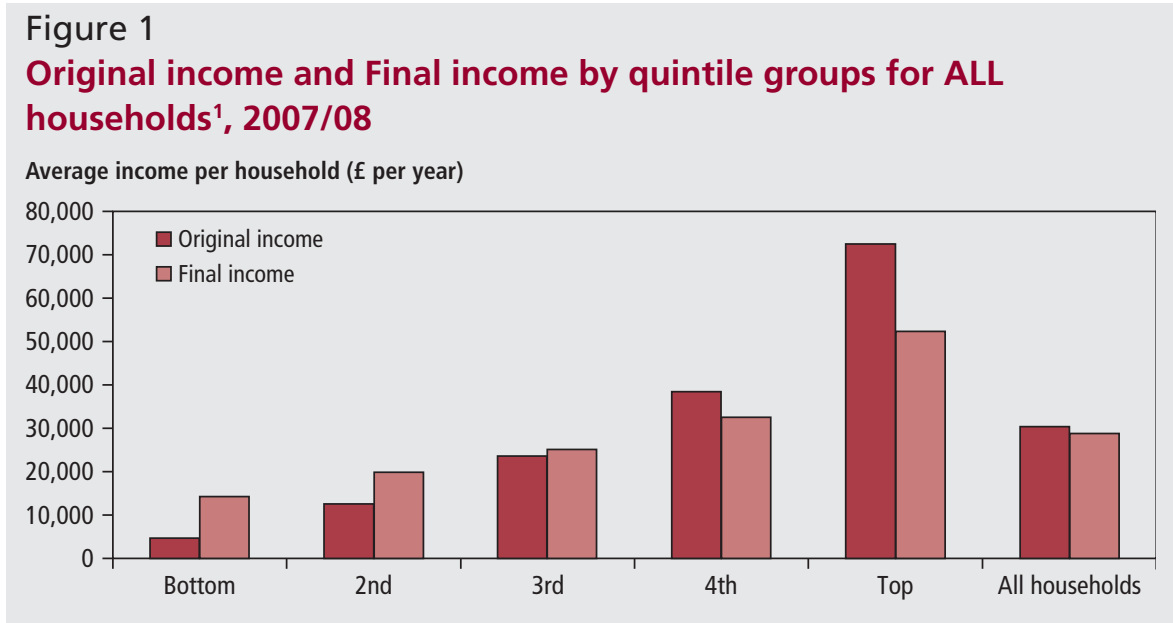

Note:

1 Households are ranked throughout by their grossed equivalised disposable incomes.

\section{Figure 2}

Gross Income by quintile groups for ALL households ${ }^{1}, 2007 / 08$

Average income per household ( $f$ per year)

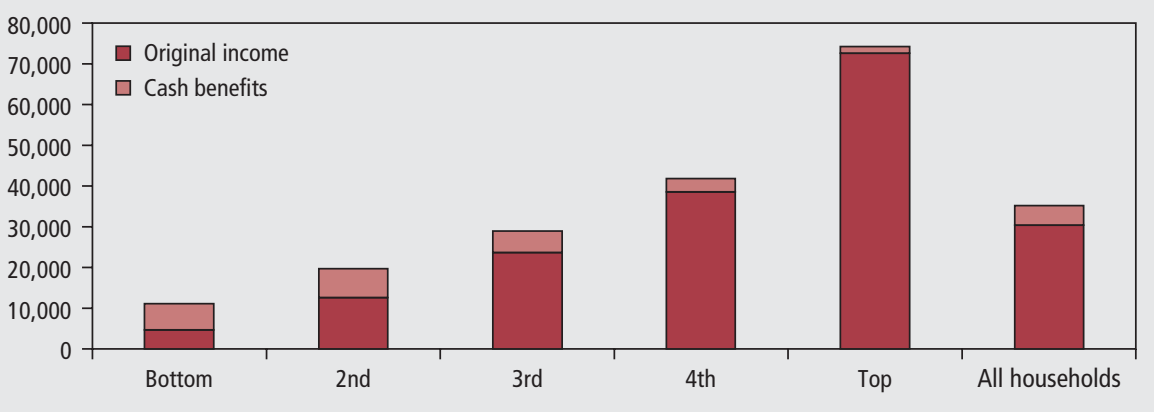

Note:

1 Households are ranked throughout by their grossed equivalised disposable incomes.

Households containing two adults with children tend to have lower incomes than those with no children. Households which consist of only one adult with children are much more concentrated in the lower income groups. Retired households also tend to have lower incomes.

\section{Trends in income inequality}

Disposable income is defined as gross income minus direct taxes. Inequality of disposable income, as measured by the Gini coefficient, was almost unchanged between 2006/07 and 2007/08, as shown in Figure 5. Income inequality has remained at roughly the same level since 1987 .

Income inequality increased rapidly in the second half of the 1980s, reaching a peak in 1990. After 1990 the trend was downwards, although inequality did not decrease to the levels of the early 1980s. After 1995/96 inequality began to rise again reaching a peak in 2001/02 - at a level very similar to that in 1990. Inequality of income fell between 2001/02 and 2004/05 before rising again in the years to $2006 / 07$. For details of how the Gini coefficient is calculated see Appendix 2, paragraph 53.

\section{Concepts and Sources}

This analysis looks at how taxes and benefits affect the distribution of income. Diagram 1 shows the stages in the redistribution of income used in this analysis. Household members receive income from employment, occupational pensions, investments and from other non-government sources. The diagram shows the various ways that government raises revenue from households through taxation and distributes benefits to them in cash, and in kind.

The analysis only allocates those taxes and benefits that can reasonably be attributed to households. Therefore, some government revenue and expenditure is not allocated, such as revenue from corporation tax and expenditure on defence and public order. There are three main reasons for not including some taxes and benefits in the analysis. Some taxes and benefits fall on people who do not live in private households. In other cases, there is no clear conceptual basis for allocation to particular households. Finally, there may be a lack of data to enable allocation. In this study, some $£ 359$ billion of taxes and compulsory social contributions have been allocated to households. This is equivalent to 61 per cent of general government expenditure, which totalled $£ 593$ billion in 2007. Similarly, $£ 321$ billion of cash benefits and benefits in kind have been allocated to households, making up 54 per cent of general government expenditure. These proportions are broadly the same to those in recent years' analyses.

The estimated values of taxes and benefits reflect the methodology used in this study. They are based on assumptions about which taxes and benefits should be covered and to whom they should apply. Where it is practical, the methodology used is similar to that used in previous years. However, there have been some changes in the underlying surveys and improvements in the methodology. For this reason, one should be cautious about making direct comparisons with earlier years. Comparisons with previous years are also affected by sampling error (for more details see Appendix 2, paragraph 57). This is especially true for estimates which are based on sub-samples such as the results for decile or quintile groups, or particular types of household. Time series are presented for some of the more robust measures, and these include Gini coefficients and other measures of inequality.

\section{Unit of analysis}

The unit of analysis used in this study is the household. The households are ranked by their equivalised disposable income, which the analysis uses as a proxy for standard of living. Equivalisation is a process that adjusts households' incomes to take account of their size and composition, to recognise that this affects the demand on resources. For example, a couple with a child would need a higher income than a childless couple for the two households to achieve the same standard of living. The equivalence scale used in this analysis is the McClements scale (before housing costs are deducted). In the earlier example, a childless couple's income of $£ 10,000$ is treated as equivalent to an income of $£ 12,300$ for a couple with a ten year old child (see Appendix 2, paragraph 48). Households with the same equivalised income do not necessarily have the same standard of living where other characteristics are different. For example, 


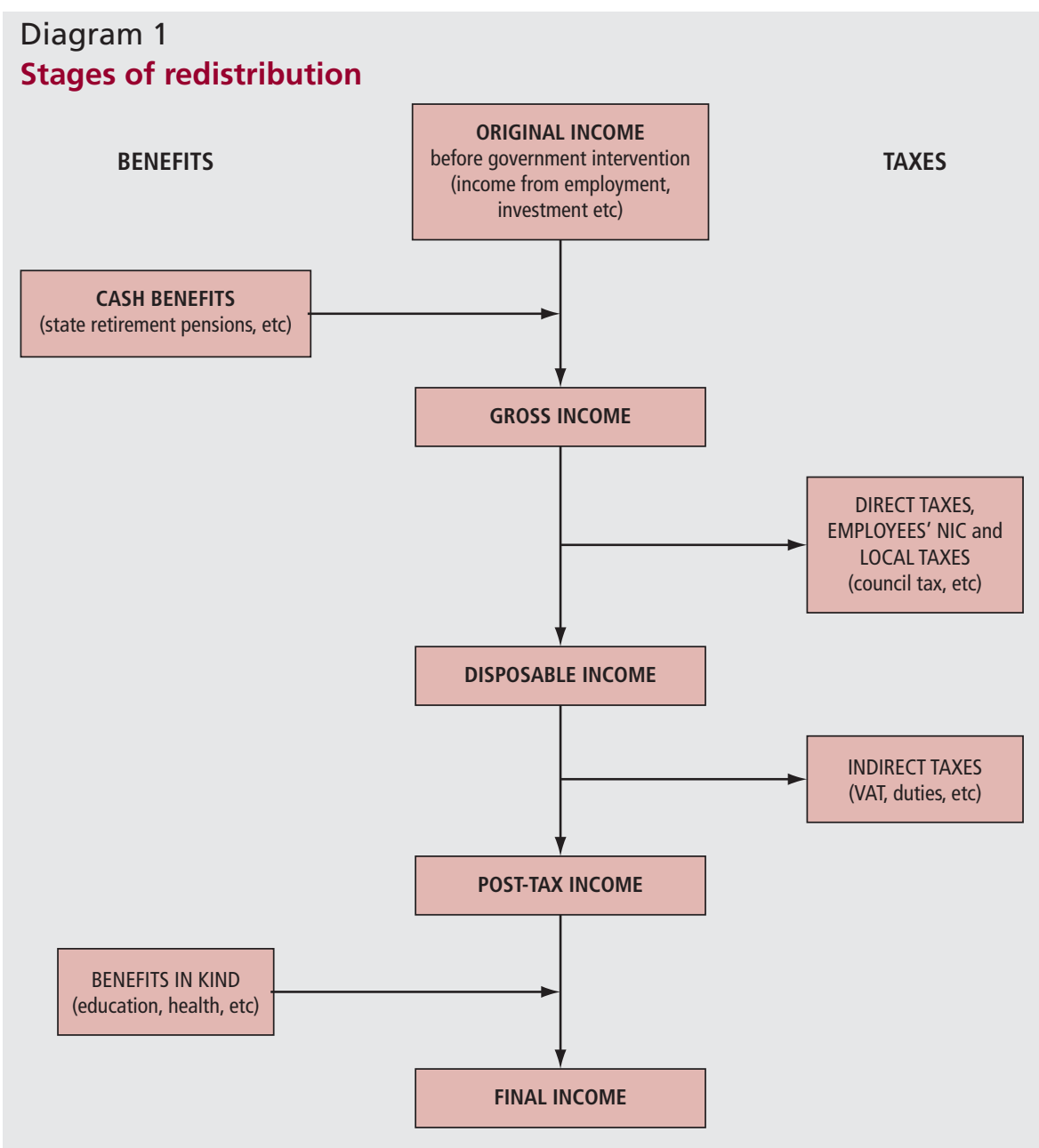

households which own their homes outright would be in a better position than identical households with the same income which had to pay rent or mortgage payments. Equivalisation does not adjust for these differences.

Equivalised income is used only to rank the households. Most monetary values shown in the analysis are not equivalised. Where equivalised amounts are given, they are shown in italics. Once the households have been ranked, the distribution is split into five or ten equally sized groups - that is quintile groups or decile groups. The bottom quintile (or decile) group is that with the lowest equivalised disposable incomes, while the top quintile (or decile) is that with the highest.

\section{Data sources}

The main data source for this analysis is the Expenditure and Food Survey (EFS) which covers about 6,100 households in the UK each year. It only covers private households - people living in hotels, lodging houses and in institutions, such as old peoples' homes, are excluded. The EFS is used because as well as collecting data on household income, it also collects expenditure data which are used here to weighting process for the EFS data used for this analysis has been updated to use 2001 Census data, for further details please refer to Appendix 2, paragraph 5.
There is known to be a degree of underreporting in the EFS for some benefits. For example, when compared to administrative data from HM Revenue and Customs (HMRC), the EFS estimate of total tax credit payments is only around two-thirds of the HMRC figure. Further details of the concepts and methodology used are given in Appendix 2.

The results of the analysis are reported in three sections. The first looks at the effects for all households. Non-retired and retired households have distinct income and expenditure patterns and so the tax and benefit systems affect the two groups in very different ways. Therefore, the second and third sections look separately at results for non-retired and retired households.

\section{Results for all households \\ Overall effect}

Taken as a whole the tax and benefit system leads to income being shared more equally between households. In this analysis, income before taxes and benefits is termed original income and includes income from earnings, occupational pensions and investments. Original income varies considerably between households. Those in the top quintile group have an average of $£ 72,600$ compared with $£ 4,700$ per year for the bottom group (Table 1).

The extent of inequality in this measure of income can be seen by looking at the proportion of total original income received by groups of households in different parts of the income distribution. At this stage, 
Table 2

\section{Percentage shares of household income and Gini coefficients, ${ }^{1}$ 2007-08}

\begin{tabular}{|c|c|c|c|c|}
\hline & \multicolumn{4}{|c|}{ Percentage shares of equivalised income for ALL households ${ }^{2}$} \\
\hline & $\begin{array}{l}\text { Original } \\
\text { income }\end{array}$ & $\begin{array}{r}\text { Gross } \\
\text { income }\end{array}$ & $\begin{array}{r}\text { Disposable } \\
\text { income }\end{array}$ & $\begin{array}{r}\text { Post-tax } \\
\text { income }\end{array}$ \\
\hline \multicolumn{5}{|l|}{ Quintile group ${ }^{2}$} \\
\hline Bottom & 3 & 7 & 7 & 6 \\
\hline 2nd & 8 & 11 & 12 & 12 \\
\hline $3 r d$ & 14 & 16 & 16 & 16 \\
\hline 4th & 24 & 22 & 22 & 22 \\
\hline Top & 51 & 44 & 42 & 44 \\
\hline All households & 100 & 100 & 100 & 100 \\
\hline \multicolumn{5}{|l|}{ Decile group ${ }^{2}$} \\
\hline Bottom & 1 & 3 & 3 & 2 \\
\hline Top & 33 & 28 & 26 & 28 \\
\hline Gini coefficient (per cent) & 52 & 38 & 34 & 38 \\
\hline
\end{tabular}

Source: Office for National Statistics

\section{Notes:}

1 This is a measure of the dispersion of each definition of income (see Appendix 2, paragraph 51).

2 Households are ranked by equivalised disposable income. the richest fifth of households (those in the top quintile group) receive 51 per cent of all original income (Table 2). This compares with only 3 per cent for households in the bottom fifth.

Adding cash benefits to original income gives gross income. In contrast to original income, the amount received from cash benefits is higher for households lower down the income distribution than for those at the top. Of the total amount of cash benefits received, the bottom two quintile groups together receive 57 per cent. These households receive an average of $£ 6,800$ per year from cash benefits, representing around 58 per cent of gross income for the bottom quintile group and 36 per cent for the second quintile group. This reduces the inequality of income.

\section{Direct taxes}

Direct taxes include income tax, national insurance contributions (NICs) and council tax or Northern Ireland rates.

Households with higher incomes pay both higher amounts of direct tax and higher proportions of their income in direct tax with the top quintile group paying an average of $£ 18,500$ per household in direct taxes. In contrast, the direct tax bill for households in the bottom quintile group is around $£ 1,200$. Consequently, direct taxes also reduce inequality of income. Looking at income tax on its own, the top two quintile groups pay 79 per cent of total income tax, while the bottom two quintile groups together pay 8 per cent.

Table 3 shows the effect of direct and indirect tax on each quintile group. Households at the lower end of the income distribution pay smaller amounts of direct tax compared with higher income households. In addition, low income households also pay a smaller proportion of their income in income tax because tax is not paid on the first tranche of

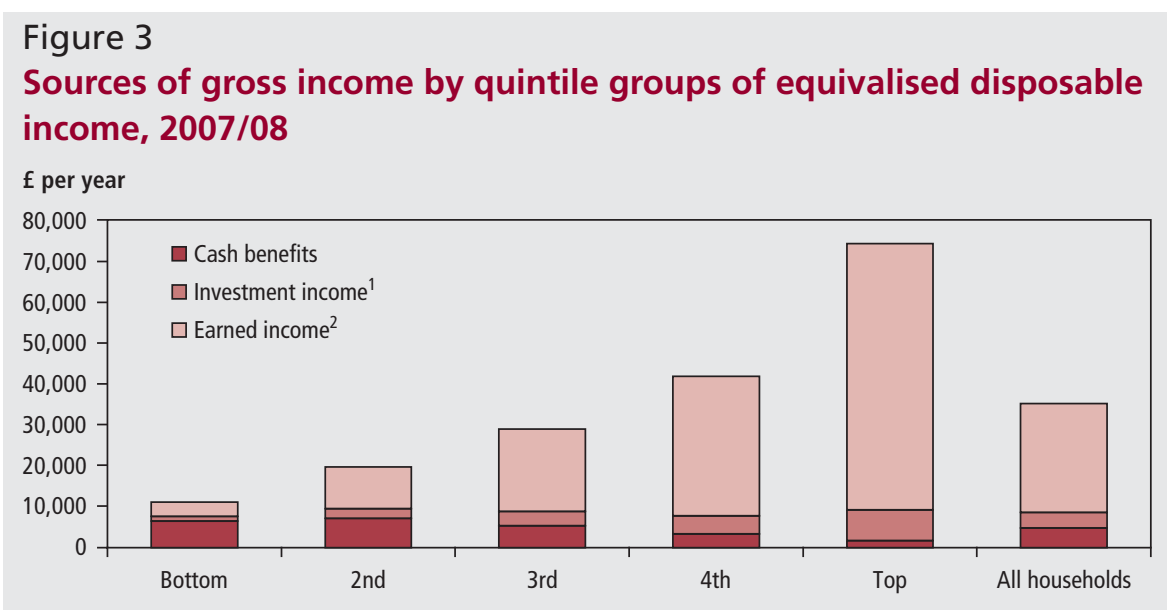

\section{Notes:}

1 Investment income includes occupational pensions and annuities.

2 Earned income includes wages and salaries, income from self-employment and income from "fringe benefits". income and higher rates of tax are paid on higher incomes. As a proportion of their gross incomes, households in the bottom quintile group pay an average of 4 per cent in income tax compared with 18 per cent for those in the top quintile group. The proportion of gross income paid in employees' National Insurance Contributions (NICs) rises with income until the third quintile group.

Council tax (and domestic rates in Northern Ireland) on the other hand are regressive even after taking into account council tax benefits and rates rebates. Households in the lower part of the income distribution pay smaller absolute amounts - average net payments by the bottom fifth of households are half those of the top fifth. However, when expressed as a proportion of gross income, the burden decreases as income rises. Council tax in Great Britain and domestic rates in Northern Ireland represent 6 per cent of gross income for those in the bottom fifth but only 2 per cent for those in the top fifth.

\section{Indirect taxes}

The amount of indirect tax each household pays is determined by their expenditure rather than their income. While the payment of indirect taxes can be expressed as a percentage of gross income in the same way as for direct taxes, it should be remembered that for some households, particularly towards the bottom of the income distribution, annual expenditure exceeds annual income. For these households, expenditure is not being funded entirely from income. To express the payment of indirect taxes as a percentage of gross or disposable income is potentially misleading because for these households their expenditure will be a better indicator of standard of living than their income. Therefore, payment of indirect taxes is also presented as a percentage of expenditure.

There are a number of possible reasons why expenditure may exceed income. Some households with low incomes may draw on their savings or borrow in order to finance their expenditure. In addition, the bottom decile in particular includes some groups who have, or report, very little income (for example people not currently in employment and some self-employed people). For some people this spell of very low income may only be temporary and, during this period, they may continue with previous patterns of spending. Some types of one-off receipts are not included as current income in the EFS, for example, inheritance and severance payments. In 


\section{Table 3}

Taxes as a percentage of gross income, disposable income and expenditure for ALL households by quintile groups, ${ }^{1}$ 2007/08

\begin{tabular}{|c|c|c|c|c|c|c|}
\hline & \multicolumn{5}{|c|}{ Quintile groups of ALL households ${ }^{2}$} & \multirow{2}{*}{$\begin{array}{r}\text { All } \\
\text { households }\end{array}$} \\
\hline & Bottom & 2nd & 3 rd & 4th & Top & \\
\hline \multicolumn{7}{|l|}{$\begin{array}{l}\text { (a) Direct and indirect taxes as a percentage of } \\
\text { gross income }\end{array}$} \\
\hline \multicolumn{7}{|l|}{ Direct taxes } \\
\hline Income tax & 3.2 & 6.9 & 10.7 & 13.5 & 18.4 & 13.7 \\
\hline Employees' NIC & 1.5 & 3.1 & 4.6 & 5.5 & 4.7 & 4.5 \\
\hline Council tax \& Northern Ireland rates ${ }^{4}$ & 6.1 & 4.0 & 3.4 & 2.8 & 1.8 & 2.8 \\
\hline All direct taxes & 10.8 & 14.1 & 18.6 & 21.8 & 24.9 & 21.0 \\
\hline \multicolumn{7}{|l|}{ Indirect taxes } \\
\hline VAT & 10.8 & 7.2 & 6.5 & 5.8 & 4.5 & 5.8 \\
\hline Duty on alcohol & 1.5 & 1.0 & 0.9 & 0.8 & 0.6 & 0.8 \\
\hline Duty on tobacco & 2.6 & 1.8 & 1.2 & 0.7 & 0.3 & 0.8 \\
\hline Duty on hydrocarbon oils \& vehicle excise duty & 3.2 & 2.3 & 2.2 & 1.9 & 1.2 & 1.8 \\
\hline Other indirect taxes & 9.9 & 6.3 & 5.3 & 4.4 & 3.5 & 4.7 \\
\hline All indirect taxes & 27.9 & 18.6 & 15.9 & 13.7 & 10.0 & 13.9 \\
\hline All taxes & 38.7 & 32.7 & 34.6 & 35.4 & 34.9 & 35.0 \\
\hline \multicolumn{7}{|c|}{ (b) Indirect taxes as a percentage of disposable income } \\
\hline VAT & 12.1 & 8.4 & 8.0 & 7.4 & 5.9 & 7.4 \\
\hline Duty on alcohol & 1.6 & 1.2 & 1.1 & 1.1 & 0.8 & 1.0 \\
\hline Duty on tobacco & 2.9 & 2.1 & 1.4 & 0.9 & 0.4 & 1.1 \\
\hline Duty on hydrocarbon oils \& vehicle excise duty & 3.6 & 2.7 & 2.7 & 2.4 & 1.5 & 2.2 \\
\hline Other indirect taxes & 11.1 & 7.4 & 6.5 & 5.7 & 4.6 & 6.0 \\
\hline All indirect taxes & 31.3 & 21.7 & 19.6 & 17.5 & 13.3 & 17.7 \\
\hline \multicolumn{7}{|l|}{ (c) Indirect taxes as a percentage of expenditure ${ }^{2}$} \\
\hline VAT & 7.9 & 7.9 & 7.8 & 7.7 & 7.1 & 7.5 \\
\hline Duty on alcohol & 1.1 & 1.1 & 1.1 & 1.1 & 1.0 & 1.0 \\
\hline Duty on tobacco & 1.9 & 2.0 & 1.4 & 0.9 & 0.4 & 1.1 \\
\hline Duty on hydrocarbon oils \& vehicle excise duty & 2.3 & 2.5 & 2.6 & 2.5 & 1.8 & 2.3 \\
\hline Other indirect taxes & 7.2 & 7.0 & 6.3 & 5.9 & 5.5 & 6.1 \\
\hline All indirect taxes & 20.3 & 20.5 & 19.2 & 18.1 & 15.8 & 18.1 \\
\hline
\end{tabular}

Source: Office for National Statistics

\section{Notes:}

1 Households are ranked by equivalised disposable income.

2 Calculated to be consistent with disposable income. See paragraph 35 of Appendix 2 for the definition of expenditure.

3 After deducting tax credits and tax relief at source on life assurance premiums.

4 After deducting discounts, council tax benefits and rates rebates. some cases, the information given on direct tax is not consistent with that on income received, possibly because of timing differences. The income and expenditure data are measured in different ways in the EFS, and either could be affected by measurement errors of different kinds (see Appendix 2, paragraph 6).

\section{Figure 4 \\ Summary of the effects of taxes and benefits on ALL households, 2007/08}

Average income per household ( $\mathrm{f}$ per year)

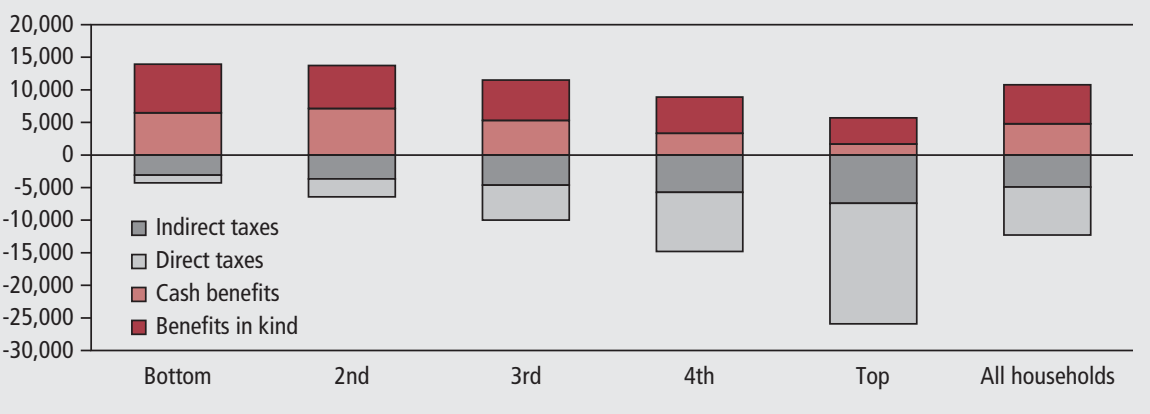

Note:

1 Households are ranked throughout by their grossed equivalised disposable incomes.
To give a more complete picture of the impact of indirect taxes, they are shown in Table 3 separately as a proportion of gross income, disposable income and expenditure. Direct taxes are also shown as a proportion of gross income so that the impact of direct and indirect taxes can be compared.

In cash terms, the top fifth of households pay almost two and a half times as much indirect tax as the bottom fifth. This simply reflects higher expenditure by higher income households. The only indirect taxes where average payments do not vary much across the income distribution are duties on tobacco, television licences, taxes on betting, and the tax element of the National Lottery.

When expressed as a percentage of expenditure, the proportion paid in indirect tax tends to be lower for households at the top of the distribution compared with those lower down (16 per cent for the top quintile compared with 20 per cent for the bottom quintile). The higher percentage of expenditure by low income groups on tobacco (1.9 per cent of total expenditure for the bottom quintile group compared with 0.4 per cent for the top quintile group) accounts for part of this difference.

When expressed as a proportion of gross or disposable income, the impact of indirect taxes declines much more sharply as income rises. This is because those in higher income groups tend to channel a larger proportion of their income into savings and mortgage payments, which do not attract indirect taxes. In addition, for many households in the lower half of the distribution, recorded current expenditure is greater than recorded current income. As a result, indirect taxes expressed as a proportion of income appear more regressive than when expressed as a proportion of expenditure.

The final stage in the redistribution process is the addition of benefits in kind, such as those from state education and the health service. Households in the bottom quintile group receive the equivalent of around $£ 7,500$ per year from all benefits in kind, compared with $£ 4,100$ received by the top fifth (see Figure 4). These are described in more detail later in the analysis.

Estimates of final income include receipt of all benefits and payment of all taxes. After redistribution through taxes and benefits, the share of income received by the bottom quintile group increased from 3 per cent for original income to 6 per cent for post tax income. The share of income received by the top quintile group fell from 51 per cent to 44 per cent. 
The effect of taxes and benefits on income inequality can be seen by their effect on the Gini coefficient. It can take values from 0 to 100 per cent where a value of zero would indicate that each household had an equal share of income, while higher values indicate greater inequality.

The Gini coefficients which appear in Table 2 produce a similar picture to the shares of income discussed earlier. For 2007/08, the figure of 52 per cent for original income is reduced to 38 per cent for gross income by the inclusion of cash benefits - a large reduction in inequality. The coefficient for disposable income shows the equalising effect of direct taxes with the figure falling further to 34 per cent. Indirect taxes reverse this effect, as the Gini coefficient is increased to 38 per cent for post-tax income.

\section{Characteristics of households}

Some types of household are more likely to be located in one part of the income distribution than another and hence it is possible to provide analysis of how different household characteristics may affect households' incomes. Information about the characteristics of households in the different income groups is shown in Table 4. Household size does not vary much across the income distribution, with an average of between 2.2 and 2.5 people per household in each quintile group in 2007/08. There are fewer children in the upper part of the income distribution. Men are slightly more likely to be in the upper part of the distribution while women are spread more evenly across the distribution. Higher income groups also contain more economically active people. The top fifth of households have almost three times as many economically active people as the bottom fifth.

Among non-retired two adult households, those without children tend to be concentrated towards the top of the income distribution with 62 per cent in the top two quintiles, while those with more children are lower down. For two adult households with children, the position in the income distribution tends to vary according to the number of children. Households with more children, unless there is a corresponding increase in income, will have lower equivalised incomes to reflect the additional demand on resources. Non-retired households with one adult and one or more children are concentrated in the lower groups. Around 67 per cent of these households are in the bottom two quintile groups.
Table 4

\section{Summary of household characteristics of quintile groups of ALL households, ${ }^{1}$ 2007-08}

\begin{tabular}{|c|c|c|c|c|c|c|}
\hline & \multicolumn{6}{|c|}{ Quintile groups of ALL households ${ }^{1}$} \\
\hline & Bottom & 2nd & $3 r d$ & 4th & Top & $\begin{array}{r}\text { All } \\
\text { households }\end{array}$ \\
\hline \multicolumn{7}{|c|}{ Number of individuals per household } \\
\hline Children $^{2}$ & 0.6 & 0.6 & 0.6 & 0.5 & 0.4 & 0.5 \\
\hline Adults & 1.7 & 1.8 & 1.9 & 2.0 & 1.8 & 1.8 \\
\hline Men & 0.8 & 0.8 & 0.9 & 1.0 & 1.0 & 0.9 \\
\hline Women & 0.9 & 1.0 & 1.0 & 1.0 & 0.9 & 1.0 \\
\hline People & 2.3 & 2.3 & 2.4 & 2.5 & 2.2 & 2.4 \\
\hline People in full-time education & 0.7 & 0.5 & 0.5 & 0.5 & 0.3 & 0.5 \\
\hline Economically active people & 0.6 & 0.8 & 1.3 & 1.6 & 1.6 & 1.2 \\
\hline Retired people & 0.6 & 0.6 & 0.5 & 0.3 & 0.2 & 0.4 \\
\hline \multicolumn{7}{|c|}{ Household type (percentages) } \\
\hline Retired & 39 & 40 & 29 & 16 & 7 & 26 \\
\hline \multicolumn{7}{|l|}{ Non-retired } \\
\hline 1 adult without children & 16 & 9 & 10 & 14 & 21 & 14 \\
\hline 2 adults without children & 11 & 14 & 19 & 29 & 43 & 23 \\
\hline 1 adult with children ${ }^{3}$ & 12 & 8 & 5 & 3 & 1 & 6 \\
\hline 2 adults with children & 14 & 18 & 22 & 21 & 19 & 19 \\
\hline 3 or more adults ${ }^{4}$ & 8 & 11 & 15 & 17 & 8 & 12 \\
\hline All household types & 100 & 100 & 100 & 100 & 100 & 100 \\
\hline
\end{tabular}

Source: Office for National Statistics

\section{Notes:}

1 Households are ranked by equivalised disposable income.

2 Children are defined as people aged under 16 or aged between 16 and 18, unmarried and receiving non-advanced further education.

3 This group is smaller than the category of 'one parent families' because some of these families will be contained in the larger household types.

4 With or without children.
Retired households are over-represented at the lower end of the distribution with 60 per cent falling into the bottom two quintile groups. Among single person retired households, women are both more numerous and also more concentrated towards the bottom of the income distribution compared with men.

\section{Changes in inequality over time}

There are several ways of measuring income inequality of which the Gini coefficient is one of the most widely used. It is described in more detail in Appendix 2, while Figure 5 shows how the Gini coefficients for the various measures of income have changed since 1982. As with other estimates presented here, they are subject to sampling error and some caution is needed particularly in the interpretation of year-to-year changes. However, by looking at data over several years it is possible to see some underlying trends.

As shown in Figure 5, the Gini coefficient for disposable income was almost unchanged between 2006/07 and 2007/08

\section{Figure 5}

\section{Gini coefficients 1982 to $2007 / 08$}

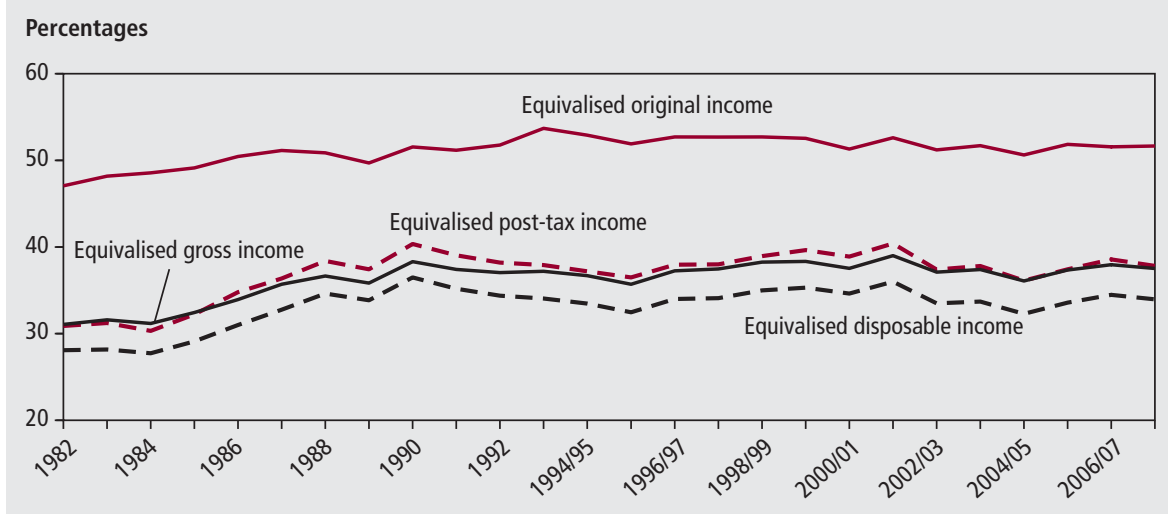


Nonetheless, the general trend of increase between 2004/05 and 2007/08 was due to increased inequality of original income. It was due in part to the faster rate of growth of wages and salaries and investment income in the upper part of the distribution compared with the lower part.

The Department for Work and Pensions (DWP) publishes analysis each year of the income distribution in their publication Households Below Average Income (HBAI), based on data from the Family Resources Survey. The Gini coefficients for disposable income in HBAI were also marginally higher in 2007/08 and 2006/07 compared with 2004/05. Due to HBAI being based on a different survey, and some conceptual differences (for example, the use of a different equivalisation scale), HBAI estimates will differ slightly. However, the underlying trends between 2004/05 and $2007 / 08$ are similar.

The recent growth in inequality followed a period between 2001/02 and 2004/05 when income inequality was falling. Over this period there was a slight fall in inequality of original income due to faster growth in income from earnings and selfemployment income at the bottom end of the income distribution. Policy changes such as the increases in the national minimum wage, increases in tax credit payments, and the increase in national insurance contributions in 2003/04 would also have resulted in small reductions in inequality of disposable and post-tax income during this period.

Inequality of disposable income increased in the late 1980s and late 1990s during periods of faster growth in income from employment, and fell in the early 1990s during a period of slower growth in employment income. Households which typically benefit the most during periods of growth in employment income are those in the middle and upper part of the income distribution. This is due to there being a much higher proportion of economically active adults in higher quintile households compared with households in the lower part of the income distribution.

The Institute for Fiscal Studies (IFS) in their report 'Permanent Differences? Income and Expenditure Inequality in 1990s and 2000s' has investigated some of the possible reasons for the higher level of inequality since 1990. There has been an increase in wage inequality, and particularly an increase in the gap between wages for skilled and unskilled workers. Suggested reasons include skills-biased technological change, a decline in the role of trade unions, and a growth in selfemployment income. There has also been a decrease in the rate of male participation in the labour market, often in households where there is no other earner, as well as increased female participation among those with working partners. This has lead to an increased polarisation between two-earner and zero-earner households. In the late 1990s, the proportion of people in workless households started to fall slowly, probably contributing to the small reduction in inequality of original income seen since 2001/02.

\section{Results for non-retired households}

This section looks at the effect of taxes and benefits on the income of nonretired households. It examines how the characteristics of non-retired households affect the receipt of benefits and payment of taxes (for a definition of retired and non-retired households refer to Appendix 2, paragraph 9).

\section{Overall effect}

As for all households, the tax and benefit systems lead to income being shared more equally between non-retired households. Before taxes and benefits, there is less inequality of non-retired households' income, as shown in Table 5, than for all households, as shown in Table 2.

However, after the process of redistribution, inequality of post-tax income (as measured, for example, by the Gini coefficient) is very similar to that for all households. The effect of taxes and benefits is therefore smaller for non-retired households than for all households, and a summary is shown in Table 6.

\section{Characteristics of non-retired households}

There is more variation in the size of non-retired households, compared with households in total. The average non-retired household size tends to decrease as income increases. This fall is largely accounted for by the decrease in the average number of children in each household from 1.0 in the bottom quintile group to 0.4 in the top.

Although one adult households with children tend to be concentrated lower down the income distribution, this tendency is slightly less pronounced than it used to be. In 1998/99, 75 per cent of these households were in the bottom two quintile groups, which compares with 67 per cent in 2007/08.

\section{Original income}

The average original income for non-retired

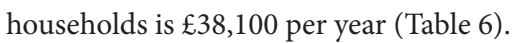
As mentioned above, inequality of original income is lower for non-retired households than for all households. For example, the ratio of the average original incomes for the top and bottom quintiles is 11 to one, compared with 16 to one for all households.

The original income of non-retired households shows a relatively strong relationship to the number of economically active people they contain. On average, households in the top three quintile groups contain almost twice as many economically active people as those in the lowest group (Table 6).

\section{Table 5}

\section{Percentage shares of household income and Gini coefficients ${ }^{1}$ for NON-RETIRED households, 2007/08}

\begin{tabular}{lrrrr}
\hline & \multicolumn{2}{c}{ Percentage shares of equivalised income for NON-RETIRED households ${ }^{2}$} \\
\cline { 2 - 5 } & $\begin{array}{c}\text { Original } \\
\text { income }\end{array}$ & $\begin{array}{c}\text { Gross } \\
\text { income }\end{array}$ & $\begin{array}{r}\text { Disposable } \\
\text { income }\end{array}$ & $\begin{array}{r}\text { Post-tax } \\
\text { income }\end{array}$ \\
\hline $\begin{array}{l}\text { Quintile group } \\
\text { Bottom }\end{array}$ & 3 & 6 & 7 & 6 \\
2nd & 10 & 12 & 12 & 12 \\
3rd & 16 & 16 & 17 & 16 \\
4th & 24 & 23 & 23 & 23 \\
Top & 46 & 41 & 44 \\
All non-retired households & 100 & 100 & 100 & 100 \\
Decile group & & & & 2 \\
Bottom & 1 & 2 & 3 & 28 \\
Top & 29 & 27 & 34 & 38 \\
Gini coefficient (per cent) & 44 & 37 & 26 & 2 \\
\hline
\end{tabular}

Source: Office for National Statistics

\section{Notes:}

1 This is a measure of the dispersion of each definition of income (see Appendix 2, paragraph 53). 2 Households are ranked by equivalised disposable income. 


\section{Table 6}

\section{Summary of the effects of taxes and benefits by quintile groups on NON-RETIRED households, ${ }^{1}$ 2007/08}

\begin{tabular}{|c|c|c|c|c|c|c|c|}
\hline & \multicolumn{6}{|c|}{ Quintile groups of NON-RETIRED households ${ }^{1}$} & \multirow{2}{*}{$\begin{array}{r}\text { Ratio } \\
\text { top/bottom } \\
\text { quintile }\end{array}$} \\
\hline & Bottom & 2nd & $3 r d$ & 4th & Top & $\begin{array}{r}\text { All non-retired } \\
\text { households }\end{array}$ & \\
\hline \multicolumn{8}{|l|}{$\begin{array}{l}\text { Income, taxes and benefits } \\
\text { per household ( } f \text { per year) }\end{array}$} \\
\hline Original income & 7502 & 21814 & 33864 & 47081 & 80185 & 38089 & 11 \\
\hline plus cash benefits & 5984 & 4816 & 2759 & 1768 & 1113 & 3288 & 0.2 \\
\hline Gross income & 13485 & 26629 & 36624 & 48849 & 81298 & 41377 & 6 \\
\hline less direct taxes ${ }^{2}$ and employees' NIC & 1561 & 4711 & 7744 & 11387 & 20510 & 9183 & 13 \\
\hline Disposable income & 11924 & 21918 & 28879 & 37462 & 60789 & 32194 & 5 \\
\hline less indirect taxes & 3661 & 4716 & 5633 & 6239 & 7776 & 5605 & 2 \\
\hline Post-tax income & 8263 & 17202 & 23247 & 31223 & 53012 & 26590 & 6 \\
\hline plus benefits in kind & 8347 & 7388 & 5950 & 5224 & 3843 & 6151 & 0.5 \\
\hline Final income & 16611 & 24591 & 29196 & 36448 & 56855 & 32740 & 3 \\
\hline \multicolumn{8}{|l|}{ Number of individuals per household } \\
\hline Children $^{3}$ & 1.0 & 0.9 & 0.6 & 0.5 & 0.4 & 0.7 & \\
\hline Adults & 1.8 & 2.0 & 2.1 & 2.1 & 1.8 & 2.0 & \\
\hline Men & 0.8 & 1.0 & 1.1 & 1.1 & 1.0 & 1.0 & \\
\hline Women & 1.0 & 1.0 & 1.0 & 1.0 & 0.9 & 1.0 & \\
\hline People & 2.8 & 2.9 & 2.7 & 2.6 & 2.2 & 2.7 & \\
\hline People in full-time education & 1.0 & 0.8 & 0.6 & 0.5 & 0.3 & 0.6 & \\
\hline Economically active people & 0.9 & 1.5 & 1.8 & 1.9 & 1.7 & 1.6 & \\
\hline Retired people & 0.1 & 0.1 & 0.1 & 0.1 & 0.1 & 0.1 & \\
\hline
\end{tabular}

Source: Office for National Statistics

\section{Notes:}

1 Households are ranked by equivalised disposable income.

2 These are income tax (which is after deducting tax credits and tax relief at source on life assurance premiums), council tax and Northern Ireland rates but after deducting discounts, council tax benefit and rates rebates.

3 Children are defined as people aged under 16 or aged between 16 and 18, unmarried and receiving non-advanced further education.

Table 7

Cash benefits for NON-RETIRED households by quintile groups, ${ }^{1}$ 2007/08

\begin{tabular}{|c|c|c|c|c|c|c|}
\hline & \multicolumn{6}{|c|}{ Quintile groups of NON-RETIRED households ${ }^{1}$} \\
\hline & Bottom & 2nd & $3 r d$ & 4th & Top & $\begin{array}{l}\text { All non-retired } \\
\text { households }\end{array}$ \\
\hline \multicolumn{7}{|l|}{ Average per household ( $f$ per year) } \\
\hline \multicolumn{7}{|l|}{ Contributory } \\
\hline Retirement pension & 321 & 714 & 578 & 639 & 455 & 542 \\
\hline Incapacity benefit & 521 & 428 & 192 & 69 & 30 & 248 \\
\hline Jobseeker's allowance ${ }^{2}$ & 70 & 40 & 5 & 1 & 2 & 24 \\
\hline Other & 64 & 89 & 58 & 147 & 137 & 99 \\
\hline Total contributory & 975 & 1271 & 833 & 856 & 624 & 912 \\
\hline \multicolumn{7}{|l|}{ Non-contributory } \\
\hline Income support ${ }^{3}$ & 1022 & 545 & 252 & 48 & 7 & 375 \\
\hline Tax $_{\text {credits }}{ }^{4}$ & 1162 & 679 & 242 & 76 & 26 & 437 \\
\hline Child benefit & 757 & 705 & 522 & 416 & 295 & 539 \\
\hline Housing benefit & 1324 & 676 & 239 & 47 & 31 & 464 \\
\hline Jobseeker's allowance ${ }^{5}$ & 148 & 36 & 1 & - & - & 37 \\
\hline Sickness/disablement related & 381 & 682 & 543 & 205 & 93 & 381 \\
\hline Other & 213 & 221 & 128 & 120 & 37 & 144 \\
\hline Total non-contributory & 5008 & 3545 & 1927 & 912 & 489 & 2376 \\
\hline Total cash benefits & 5984 & 4816 & 2759 & 1768 & 1113 & 3288 \\
\hline Cash benefits as a percentage of gross income & 44 & 18 & 8 & 4 & 1 & 8 \\
\hline
\end{tabular}

Source: Office for National Statistics

\section{Notes:}

1 Households are ranked by equivalised disposable income.

2 Contribution based.

3 Including pension credit.

4 Child tax credit and working tax credit.

5 Income based.
Cash benefits

Table 7 gives a summary of the cash benefits that each non-retired quintile group receives. There are two types of cash benefits: contributory benefits which are paid from the National Insurance Fund (to which individuals and their employers make contributions while working) and non-contributory benefits. For non-retired households, non-contributory benefits make up nearly three-quarters of all cash benefits on average.

Most non-contributory benefits, particularly income support, tax credits and housing benefit, are income related and so payments are concentrated in the two lowest quintile groups. The presence of some individuals with low incomes in high income households means that some payments are recorded further up the income distribution. Of the total amount of income support, tax credits and housing benefit paid to non-retired households, 85 per cent goes to the bottom two-fifths, with the majority of this going to the bottom quintile.

Child benefit is based on the number of children in the household. Levels of child benefit received are also higher at the lower end of the distribution, as these households tend to have more children.

In contrast to non-contributory benefits, a criterion for receipt of contributory benefits is the amount of national insurance contributions that have been paid by, or on behalf of, the individual. The amounts received from these benefits are also higher in the lower half of the distribution, but to a lesser extent than for non-contributory benefits.

Cash benefits provide 44 per cent of gross income for households in the bottom quintile group, falling to just 1 per cent for households in the top quintile. Their payment results in a significant reduction in income inequality.

\section{Direct and indirect taxes}

Tables 8 and 9 show estimates of how much direct and indirect taxes are paid by nonretired households. The patterns are similar to those described for all households.

As noted for all households, national insurance contributions as a proportion of gross income increase from the first to the fourth quintile group, but are then lower for the top fifth of households. In 2007/08, employees NICs were levied at 11 per cent on weekly earnings from $£ 100$ to $£ 670$ and at 1 per cent above this. Many people in households in the top quintile group will have a significant part of their earnings 
Table 8

Taxes as a percentage of gross income for NON-RETIRED households by quintile groups, ${ }^{1}$ 2007/08

\begin{tabular}{|c|c|c|c|c|c|c|}
\hline & \multicolumn{6}{|c|}{ Quintile groups of NON-RETIRED households ${ }^{1}$} \\
\hline & Bottom & 2nd & $3 r d$ & 4th & Top & $\begin{array}{l}\text { All non-retired } \\
\text { households }\end{array}$ \\
\hline \multicolumn{7}{|l|}{ Percentages } \\
\hline \multicolumn{7}{|l|}{ Direct taxes } \\
\hline Income tax ${ }^{2}$ & 4.4 & 9.3 & 12.3 & 14.7 & 18.8 & 14.5 \\
\hline Employees' NIC & 2.6 & 4.9 & 5.9 & 6.2 & 4.7 & 5.2 \\
\hline Council tax \& NI rates ${ }^{3}$ & 4.5 & 3.5 & 2.9 & 2.5 & 1.7 & 2.5 \\
\hline All direct taxes & 11.6 & 17.7 & 21.1 & 23.3 & 25.2 & 22.2 \\
\hline All indirect taxes & 27.1 & 17.7 & 15.4 & 12.8 & 9.6 & 13.5 \\
\hline All taxes & 38.7 & 35.4 & 36.5 & 36.1 & 34.8 & 35.7 \\
\hline
\end{tabular}

Source: Office for National Statistics

Notes:

1 Households are ranked by equivalised disposable income.

2 After deducting tax credits and tax relief at source on life assurance premiums.

3 Council tax and Northern Ireland rates after deducting discounts, council tax benefit and rates rebates.

Table 9

Indirect taxes as a percentage of (a) disposable income and (b) household expenditure ${ }^{1}$ for NON-RETIRED households by quintile groups, ${ }^{2}$ 2007/08

\begin{tabular}{|c|c|c|c|c|c|c|}
\hline & \multicolumn{6}{|c|}{ Quintile groups of NON-RETIRED households ${ }^{2}$} \\
\hline & Bottom & 2nd & $3 r d$ & 4th & Top & $\begin{array}{l}\text { All non-retired } \\
\text { households }\end{array}$ \\
\hline \multicolumn{7}{|l|}{ (a) Percentages of disposable income } \\
\hline VAT & 11.6 & 8.4 & 7.9 & 7.2 & 5.7 & 7.3 \\
\hline Duty on alcohol & 1.5 & 1.2 & 1.2 & 1.0 & 0.8 & 1.0 \\
\hline Duty on tobacco & 3.2 & 2.0 & 1.4 & 0.8 & 0.3 & 1.1 \\
\hline Duty on hydrocarbon oils \& vehicle excise duty & 3.6 & 2.9 & 2.8 & 2.4 & 1.4 & 2.3 \\
\hline Other indirect taxes & 10.7 & 7.0 & 6.2 & 5.3 & 4.5 & 5.8 \\
\hline All indirect taxes & 30.7 & 21.5 & 19.5 & 16.7 & 12.8 & 17.4 \\
\hline \multicolumn{7}{|l|}{ (b) Percentages of expenditure ${ }^{1}$} \\
\hline VAT & 7.7 & 7.6 & 7.7 & 7.5 & 6.9 & 7.4 \\
\hline Duty on alcohol & 1.0 & 1.1 & 1.2 & 1.0 & 1.0 & 1.0 \\
\hline Duty on tobacco & 2.1 & 1.8 & 1.3 & 0.8 & 0.4 & 1.1 \\
\hline Duty on hydrocarbon oils \& vehicle excise duty & 2.4 & 2.6 & 2.7 & 2.5 & 1.7 & 2.3 \\
\hline Other indirect taxes & 7.1 & 6.4 & 6.0 & 5.6 & 5.4 & 5.9 \\
\hline All indirect taxes & 20.4 & 19.5 & 18.9 & 17.5 & 15.4 & 17.7 \\
\hline
\end{tabular}

Source: Office for National Statistics

Notes:

1 Calculated to be consistent with disposable income. See paragraph 35 of Appendix 2 for the definition of expenditure.

2 Households are ranked by equivalised disposable income.

Table 10

Benefits in kind for NON-RETIRED households by quintile groups, ${ }^{1}$ 2007/08

\begin{tabular}{|c|c|c|c|c|c|c|}
\hline & \multicolumn{6}{|c|}{ Quintile groups of NON-RETIRED households ${ }^{1}$} \\
\hline & Bottom & 2nd & $3 r d$ & 4th & Top & $\begin{array}{l}\text { All non-retired } \\
\text { households }\end{array}$ \\
\hline \multicolumn{7}{|l|}{ Average per household (f per year) } \\
\hline Education & 5260 & 4096 & 3100 & 2287 & 1223 & 3193 \\
\hline National health service & 2870 & 3137 & 2738 & 2809 & 2406 & 2792 \\
\hline Housing subsidy & 46 & 26 & 14 & 6 & 3 & 19 \\
\hline Travel subsidies & 64 & 90 & 86 & 118 & 211 & 114 \\
\hline School meals and welfare milk & 106 & 40 & 13 & 4 & 1 & 33 \\
\hline All benefits in kind & 8347 & 7388 & 5950 & 5224 & 3843 & 6151 \\
\hline Benefits in kind as a percentage of post-tax income & 101 & 43 & 26 & 17 & 7 & 23 \\
\hline
\end{tabular}

Source: Office for National Statistics

Note:

1 Households are ranked by equivalised disposable income. taxed at this lower rate and hence they will contribute less, as a proportion of their income.

\section{Benefits in kind}

The Government provides a number of goods and services to households that are either free at the time of use or at subsidised prices. These goods and services can be assigned a monetary value and this analysis allocates this value to individual households. The addition of benefits in kind to disposable income results in an estimate of households' final income. The largest two categories for which a value is assigned are health and education services and, in total, six categories are assigned values. The value given to these benefits is based on the estimated cost of providing them, which for all households is detailed in Table 13. However, the actual value to households may be greater, or smaller, than the cost to the Government of provision. Future work may investigate methods for improving these estimates.

Table $\mathbf{1 0}$ gives a summary of the value of benefits in kind for each quintile group for non-retired households. The benefit in kind from education is allocated to a household according to its members' use of state education (Appendix 2, paragraph 38). Households in the lower quintiles receive the highest benefit from education, as shown in Table 10. This is due to the concentration of children in this part of the distribution. In addition, children in households in the higher quintiles are more likely to be attending private schools and an allocation is not made in these cases. Free school meals and welfare milk go predominantly to lower income groups, where children are more likely to have school meals provided free of charge.

The benefit from the health service is estimated according to the age and sex of the household members rather than their actual use of the service, as the EFS does not contain this information (Appendix 2, paragraph 40). The assigned benefit is relatively high for young children, low in later childhood and through the adult years until it begins to rise from late middle age onwards. This benefit is similar in the first four quintiles and lower in the top group, as shown in Table 10. This pattern is a reflection of the demographic composition of households. Studies by Sefton have attempted to allow for variations in use of the health service according to socioeconomic characteristics.

The benefit given to households for the National Health Service has risen in recent 
years, reflecting increased government spending on health. Throughout the 1990s, it was equivalent to around 9 per cent of average post-tax income for non-retired households. From 2001/02 onwards, although it has fluctuated year on year, the benefit has increased and by 2007/08 was equivalent to 11 per cent of post-tax income, or an average of $£ 2,800$ per year.

The housing subsidy, which excludes housing benefit (Appendix 2, paragraph 41), fell in the years leading to 2006/07, as the proportion of households in public sector, housing association and Registered Social Landlord housing has declined. However, due to a slight change to the methodology of calculation, the average value attributed to housing subsidy rose slightly between 2006/07 and 2007/08.

Travel subsidies cover the support payments made to bus and train operating companies. The use of public transport by non-retired households is partly related to the need to travel to work and therefore to the number of economically active people in a household. This results in estimates of these subsidies being higher for households in higher income quintiles. This pattern is also due to London and the South East having higher levels of commuting by public transport together with higher than average household incomes.

Taken together, the absolute value of these benefits in kind declines as household income increases. The ratio of benefits in kind to post-tax income decreases from 101 per cent for the lowest quintile group to 7 per cent for the highest. This indicates that these benefits contribute to the reduction of inequality.

The effects of taxes and benefits by household type

The tax and benefit systems affect different types of household in different ways reflecting, in part, the number and ages of people within each household type. Of the types of non-retired households shown in Figure 6, only those containing one adult and children make significant net gains, with average final incomes of $£ 23,000$ per year compared with original incomes of $£ 11,000$. Households with two adults and three or more children, and households with three or more adults with children are also net beneficiaries, but to a smaller extent.

Original income is strongly related to the number of adults in the household. For two adult households, those with children have broadly similar levels of original income to those without, but they receive more cash

\section{Figure 6}

Income stages by non-retired household types, 2007/08

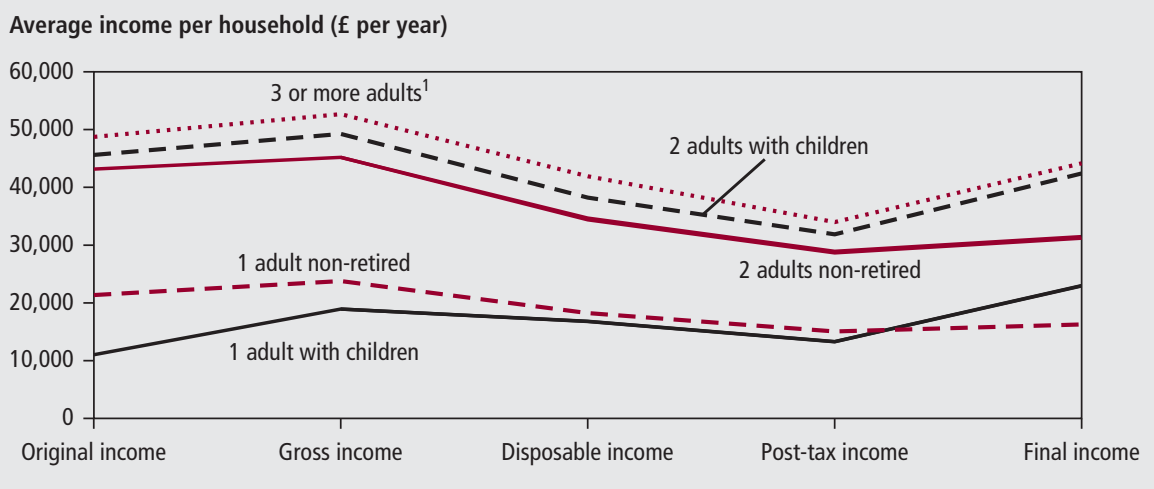

Note:

1 With or without children. benefits such as tax credits and child benefit than those without children. Final incomes are also higher for those with children due to the value assigned to education services.

For one adult households, original income is much lower for those with children as the adult is less likely to be economically active. Benefits, both in cash and in kind, are significantly higher for those with children.

\section{Results for retired households}

In this analysis retired households are those where the income of retired household members accounts for more than half of the household gross income (see Appendix 2, paragraph 9 for the definition of a retired person). These households have quite distinct income and expenditure patterns. The tax and benefit systems affect them in different ways from non-retired households.

Retired households are much more likely to be towards the bottom of the income distribution. Of retired households with two or more adults, 63 per cent are in the bottom two quintile groups. One adult male households are slightly less concentrated towards the bottom of the income distribution, with 54 per cent in the lowest two quintiles. However, among one adult female households, which outnumber one adult male households by about two and a half to one, 60 per cent are in the bottom two quintiles.

Among retired households, there is a high degree of inequality in income before taxes and benefits. Table 11 shows that, before government intervention, the richest fifth of retired households receive 57 per cent of total original income, while the Gini coefficient for this measure of income is 64 per cent. Both these measures are higher (showing more inequality) than equivalent figures for non-retired households. After the impact of taxes and benefits there is a large reduction in inequality. Cash benefits
Table 11

\section{Percentage shares of household income and Gini coefficients ${ }^{1}$ for RETIRED households, 2007/08}

\begin{tabular}{|c|c|c|c|c|}
\hline & \multicolumn{4}{|c|}{ Percentage shares of equivalised income for RETIRED households ${ }^{2}$} \\
\hline & $\begin{array}{c}\text { Original } \\
\text { income }\end{array}$ & $\begin{array}{c}\text { Gross } \\
\text { income }\end{array}$ & $\begin{array}{r}\text { Disposable } \\
\text { income }\end{array}$ & $\begin{array}{l}\text { Post-tax } \\
\text { income }\end{array}$ \\
\hline \multicolumn{5}{|l|}{ Quintile group ${ }^{2}$} \\
\hline Bottom & 3 & 9 & 9 & 8 \\
\hline 2nd & 7 & 14 & 14 & 14 \\
\hline $3 r d$ & 12 & 17 & 18 & 18 \\
\hline 4th & 21 & 22 & 22 & 22 \\
\hline Top & 57 & 39 & 37 & 38 \\
\hline All households & 100 & 100 & 100 & 100 \\
\hline \multicolumn{5}{|l|}{ Decile group ${ }^{2}$} \\
\hline Bottom & 1 & 4 & 4 & 3 \\
\hline Top & 42 & 25 & 23 & 24 \\
\hline Gini coefficient (per cent) & 64 & 29 & 27 & 31 \\
\hline
\end{tabular}

Source: Office for National Statistics

Notes:

1 This is a measure of the dispersion of each definition of income (see Appendix 2, paragraph 53).

2 Households are ranked by equivalised disposable income. 
Table 12

\section{Summary of the effects of taxes and benefits on RETIRED households by quintile groups, ${ }^{1}$ 2007/08}

\begin{tabular}{|c|c|c|c|c|c|c|}
\hline & \multicolumn{6}{|c|}{ Quintile groups of RETIRED households ${ }^{1}$} \\
\hline & Bottom & 2nd & $3 r d$ & 4th & Top & $\begin{array}{r}\text { All retired } \\
\text { households }\end{array}$ \\
\hline \multicolumn{7}{|l|}{$\begin{array}{l}\text { Income, taxes and benefits } \\
\text { per household ( } f \text { per year) }\end{array}$} \\
\hline \multicolumn{7}{|l|}{ Original income } \\
\hline Earnings & 55 & 122 & 471 & 538 & 1049 & 447 \\
\hline Occupational pensions & 981 & 2458 & 4234 & 7118 & 17116 & 6381 \\
\hline Investment income & 459 & 482 & 550 & 1067 & 6756 & 1863 \\
\hline Other income & 43 & 106 & 104 & 140 & 64 & 91 \\
\hline Total original income & 1537 & 3168 & 5359 & 8863 & 24985 & 8782 \\
\hline plus Contributory benefits & 5864 & 6997 & 6949 & 7119 & 6950 & 6776 \\
\hline Non-contributory benefits & 988 & 2011 & 2794 & 2683 & 2370 & 2169 \\
\hline Total cash benefits & 6853 & 9008 & 9743 & 9802 & 9320 & 8945 \\
\hline Gross income & 8390 & 12176 & 15102 & 18665 & 34306 & 17727 \\
\hline less Income tax ${ }^{2}$ & 149 & 365 & 694 & 1282 & 4904 & 1479 \\
\hline Employees' NIC & 8 & 3 & 31 & 22 & 69 & 27 \\
\hline Council tax \& Northern Ireland rates ${ }^{3}$ & 873 & 715 & 690 & 868 & 1224 & 874 \\
\hline Disposable income & 7360 & 11092 & 13687 & 16493 & 28109 & 15348 \\
\hline less Indirect taxes & 2327 & 2387 & 2688 & 2914 & 4364 & 2936 \\
\hline Post-tax income & 5033 & 8706 & 10999 & 13579 & 23745 & 12412 \\
\hline plus National health service & 5421 & 5470 & 4972 & 5327 & 5128 & 5264 \\
\hline Housing subsidy & 15 & 30 & 37 & 30 & 16 & 26 \\
\hline Other benefits in kind & 320 & 373 & 160 & 219 & 158 & 246 \\
\hline Final income & 10789 & 14579 & 16167 & 19154 & 29046 & 17947 \\
\hline Cash benefits as a percentage of gross income & 82 & 74 & 65 & 53 & 27 & 50 \\
\hline Retirement pension as a percentage of cash benefits & 84 & 75 & 70 & 72 & 73 & 74 \\
\hline
\end{tabular}

Source: Office for National Statistics

\section{Notes:}

1 Households are ranked by equivalised disposable income.

2 After deducting tax credits and tax relief at source on life assurance premiums.

3 Council tax and Northern Ireland rates after deducting discounts, council tax benefit and rates rebates.

play by far the largest part in bringing about this reduction. Payment of direct taxes makes a further, though much smaller, contribution. Payments of indirect taxes result in an increase in inequality.

Overall, retired households receive an average of $£ 8,800$ per year in original income with most of this coming from occupational pensions and investments (Table 12). Original income ranges from $£ 1,500$ for the bottom quintile group to $£ 25,000$ per year for the top. On the other hand, amounts received from cash benefits vary less across the distribution. On average, households in the bottom fifth receive around $£ 6,900$ per year from this source, while those in the second to fifth quintile groups receive between $£ 9,000$ and $£ 9,800$ per year. These cash benefits make up large proportions of the gross incomes for the bottom four quintiles ranging from 82 per cent for the bottom quintile group to 53 per cent for the fourth quintile group.
The top fifth are much less dependent on cash benefits - these account for only 27 per cent of their gross incomes.

Most retired people will have made contributions to the National Insurance Fund throughout their working lives. Many of the benefits which retired households receive are paid out of this fund in the form of contributory benefits. The most significant of these is the state retirement pension, which on average accounts for threequarters of retired households' cash benefits.

Non-contributory benefits are lowest in the bottom two quintile groups.

Housing benefit and disability benefits can sometimes make up a significant proportion of the income of retired households, who as a result will appear higher up the income distribution. However, this does not necessarily mean that they have a higher standard of living. Households receiving housing benefit are likely to have higher housing costs than owner occupiers (who may own their property outright), and similarly the income from disability benefits may be offset by additional costs incurred by the individual due to their illness or disability.

Retired households derive significant benefits from health services. Health benefit is spread fairly evenly between retired households and in 2007/08 was worth an average of $£ 5,300$. This is close to twice the figure for non-retired households, and increases their post tax income by 42 per cent. The benefits received by retired households from travel subsidies are mainly for bus travel, particularly in the form of concessionary fares and passes for senior citizens and, since these are not usually means-tested, there is no particular relationship with income.

Overall, retired households are major beneficiaries from redistribution through the tax and benefit system. Retired households with two or more adults have an average original income of $£ 13,100$, but a final income of $£ 22,200$. The corresponding figures for one adult retired households are $£ 5,100$ and $£ 14,300$. Among one adult households, women have a lower original income than men, but after the addition of benefits and the deduction of taxes, the differences are greatly reduced.

\section{ACKNOWLEDGEMENTS}

The author gratefully acknowledges the considerable work done for this study by Daniel Annan, Sonia Carrera and Grace Anyaegbu.

\section{REFERENCES}

Department for Work and Pensions (2007) Opportunity for All, Indicators update 2007 The Stationery Office.

Goodman A and Shephard A (2002) 'Inequality and living standards in Great Britain: some facts', The Institute for Fiscal Studies Briefing Note 19.

Goodman A and Oldfield Z (2004) 'Permanent Differences? Income and Expenditure Inequality in 1990s and 2000s', The Institute for Fiscal Studies Report No. 66.

Muriel A and Sibieta L (2009) 'Living Standards During Previous Recessions', The Institute for Fiscal Studies Briefing Note No. 85.

Sefton T (1997) 'The changing distribution of the social wage', London School of Economics and Political Science.

Sefton T (2002) 'Recent changes in the distribution of the social wage', London School of Economics and Political Science. 